\title{
Rediseño industrial de azulejos tradicionales valencianos
}

\author{
F. LUCAS* , J. V. ESCUDER , S. BERGÉ, A. ANDRÉS * J. L. PORCAR ** D. GARCíA , P. MERCE ( FOTOGRAFíAS ) ** \\ * FRITTA, S.L. \\ ** Instituto de Promoción Cerámica. Diputación Castellón.
}

\begin{abstract}
Se ha pretendido recuperar una tipología de Cerámica tradicional Valenciana, adaptando su tecnología productiva a los sistemas, instalaciones y materiales actuales.
\end{abstract}

\section{Industrial redesign of traditional valencian tiles}

\begin{abstract}
The idea behind this project was to recover a type of Traditional Valencian Ceramics, by adapting its own particular production technology to present-day systems, installations and materials.
\end{abstract}

Key words: wall, floor tile, traditional ceramics, industrial redesign

\section{INTRODUCCION Y METODOLOGÍA}

1.- Se realizó una selección de algunos modelos que representen una evolución cronológica ( siglos XV , XVI , XVII , XVIII, y XIX )

2.- Se estudiaron sus formatos, diseños, esmaltes, colores, sistemas de decoración, piezas complementarias, sistemas productivos, materiales etc.

3.- Consideraciones arquitectónicas del entorno en el que eran colocados los azulejos ( edificaciones públicas, privadas , religiosas etc )

4.- Realización de un rediseño industrial para lograr la producción actual de esta tipología de productos, utilizando las más modernas técnicas, materiales e instalaciones actuales, pero respetando al máximo sus características fundamentales : formatos, dibujos, colores, geometría de colocación etc.

No se ha intentado reeditar exactamente cada pieza, labor más propia de artesanos, sino reinterpretar una tipología de productos bastante olvidada por el sector de fabricación de pavimentos y revestimientos cerámicos. Se ha pretendido también dar a conocer la relación entre el desarrollo del sector cerámico actual en la Comunidad Valenciana y el gran auge que tuvo la producción cerámica en esta comunidad a partir del siglo $\mathrm{XV}$, en el que los centros cerámicos valencianos alcanzan un reconocimiento internacional con la producción de mayólica azul y dorada, comenzando entonces la vocación exportadora tan característica de este sector.

Los modelos así fabricados llevarán un componente cultural añadido a los componentes técnicos y estéticos habituales .

\section{INTRODUCTION AND METHODOLOGY}

1. A selection of particular models representing a chronological evolution $\left(15^{\text {th }}, 16^{\text {th }}, 17^{\text {th }}, 18^{\text {th }}\right.$ and $19^{\text {th }}$ centuries $)$ was made.

2. Their size formats, designs, enamels, colours, decoration systems, complementary items, production systems, materials, etc. were all examined.

3. Architectural considerations of the setting in which the tiles were fitted (public, private, religious buildings, etc.) were taken into account.

4. An Industrial redesign process was undertaken to allow present production of this type of products, using the most modern techniques, materials and systems, but respecting as far as possible their basic traits, size formats, designs, colours, fitting geometry, etc..

The aim was not exactly to re-edit each item, a task more suited to craftsmen, but to reinterpret a type of products largely forgotten by the wall and floor tile manufacturing sector. An attempt is also made to shed light on the relationship between the development of the present ceramic sector in the Valencian Community and the great boom in ceramic production in this community from the $15^{\text {th }}$ century, in which Valencian ceramic centres attained international prestige with the production of blue and golden maiolica, with the export trend so characteristic of the sector starting at this time.

The models made this way involve a cultural element in addition to the customary technical and aesthetic components. 


\section{PROCESO DE REDISEÑO}

\section{II.1 Diseño gráfico}

El diseño gráfico se ha realizado a partir de fotografías de piezas auténticas, mediante un tratamiento informático de esas imágenes utilizando un scaner de alta resolución y programas de tratamiento de imágenes ( Adobe Photoshop y CorellDRAW ).Las imágenes se han trabajado a una resolución de 60 pixels $/ \mathrm{cm}$. Se han separado los diferentes colores de la pieza para poder llegar al máximo de riqueza cromática empleando el mínimo número de colores en la decoración industrial.

Las pantallas serigráficas se han realizado con una tela de 77 hilos $/ \mathrm{cm}$. Los formatos se han modificado ligeramente para adaptarlos a las posibilidades productivas de las piezas actuales. En algunos casos el diseño de las piezas se ha realizado mediante una composición de cuatro piezas en una pieza de producción actual, que se corta una vez cocida.

\section{II.2 Proceso productivo:}

En todos los casos las piezas han sido realizadas en monococción de pasta roja , empleando el soporte habitual de las fábricas de la zona de Castellón.

Los esmaltes utilizados son esmaltes habituales de los empleados en la producción normal y el proceso de aplicación ha sido :

$1^{\circ}$.- Engobe aplicado a campana

$2^{\circ}$.- Esmalte aplicado a campana

$3^{\circ}$.- Serigrafías coloreadas ( desde tres a cinco ) dependiendo del modelo

$4^{\circ}$.- Esmalte protector de los colores ( para las piezas de pavimento )

La cocción se ha realizado en un horno industrial con un ciclo de 40 minutos y una temperatura máxima de $1145^{\circ} \mathrm{C}$.

En el caso de las piezas de menor formato se han fabricado componiendo cuatro en una sola pieza y cortándolos tras la cocción.

Para dar el aspecto de envejecido se ha utilizado la técnica del pulido sobre esmalte . Regulando el tipo de pulido se consigue obtener un aspecto satinado y envejecido pero con poco brillo.

\section{LOS MODELOS}

Las baldosas cerámicas seleccionadas para este proyecto de rediseño pretenden ser representativas de las grandes etapas de la evolución de la cerámica arquitectónica valenciana, desde el siglo XV hasta finales del XIX . Los modelos son los siguientes :

\section{III.1 Pavimento en el Salón Dorado del Palau de la Generalitat}

Esta noble estancia del Palau de la Generalitat debió recibir solados desde 1.480 hasta 1.568. La pavimentación actual, resultado de un proyecto de reforma ejecutado entre 1.945 y 1.952, está resuelto con baldosas cerámicas de Manises, fabricadas de forma artesanal a partir de modelos tardogóticos. Fig. 1a, b,c.

Pavimento cerámico de $9.02 \times 12.40 \mathrm{~m}$. Baldosas de mayólica, de $13 \times 13 \mathrm{~cm}$, decoradas sobre el vidriado estannífero con azul cobalto. Pintado manual a partir de la delineación con estarcido.

\section{REDESIGN PROCESS}

\section{II.1 Graphic design:}

The graphic design was made from photographs of original items, by means of computer-processing these images using a high resolution scanner and image treatment programmes (Adobe Photoshop and CorelDRAW). The images were handled at a resolution of 60 pixels $/ \mathrm{cm}$. The different colours of the item were separated to be able to reach the maximum chromatic detail using the minimum number of colours in industrial decoration.

The serigraphy screens were made with a fabric of 77 threads $/ \mathrm{cm}$.. Size formats were slightly modified to adapt these to the production possibilities of today's pieces. In some cases the design of the parts was made by means of a composition of four items in a single piece of present-day production, which was cut after being fired.

\section{II.2 Production process:}

In all the cases the items were made in a red body singlefiring system, applying the support customarily used in factories in the Castellón zone.

The enamels applied are the standard types used in normal production and the application process was as follows:

1. Bell applied engobe.

2. Bell applied enamel.

3. Coloured silk screens (from three to five) depending on the model.

4. Colour protection enamel (for the paving items).

The firing process was in an industrial kiln with a 40 minute cycle and a maximum temperature of $1145^{\circ} \mathrm{C}$.

In the case of smaller format items, these were made by combining four in a single piece and then cutting them off after firing.

To give the antique look the polishing on enamel technique was used. By adjusting the type of polishing a satin antique look with a low shine was obtained.

\section{THE MODELS}

The ceramic tiles selected for this redesign project were intended to be representative of the major stages in the evolution of Valencian architectural ceramics, from the $15^{\text {th }}$ to the late $19^{\text {th }}$ centuries. The models are as follows:

\section{III.1 Paving in the Golden Romm of the Generalitat Palace}

The paving in this splendid room in the Generalitat Palace must have been laid from 1480 to 1568 . The present paving, which is the result of a refurbishment project executed from 1945 to 1952, is a work with Manises ceramic tiles, craftsmanmade from late-Gothic models. Figs. 1a,b,c.

Ceramic paving $9.02 \times 12.40 \mathrm{~m}$. maiolica tiles, $13 \times 13 \mathrm{~cm}$. decorated over the stanniferous or tin glaze with cobalt blue. Hand-painted starting from the line-drawing with a stencil.

The layout of the designs and the grid pattern created make this a significant example of later Manises Gothic production, towards the end of the influence of Valencian tile-making. It includes the following designs:

Mitadat tiles in blue, forming a grid pattern square with the 
Ejemplo significativo, por la disposición de los diseños y la retícula creada, de la última producción gótica de Manises, en las postrimerías de la influencia de la azulejería valenciana. Incluye los siguientes diseños:

Baldosas de mitadat en azul, formando retícula a cartabón con la estancia y que alberga en su centro y sus vértices los azulejos de cuarto ornato.

Baldosas de cuarto ornato en azul sobre blanco, con diseño organizado en diagonal y enlaces en dos lados contiguos. Rama simetrizada con zarcillos, cuadrado cuarteado en la base que contiene una roseta en reserva y cordoncillo a modo de cenefa.

Baldosas de diseño completo sin enlaces, organizado según dos ejes diagonales. Versión de la rosa gótica (flor de cuatro pétalos con estambres estilizados), con cordoncillo como marco.

Estos modelos han sido reseñados en "Cerámica del Levante Español, siglos medievales". Tomo II, Azulejos-Alicatados, de M. González Martí (pág. 419, fig. 577).

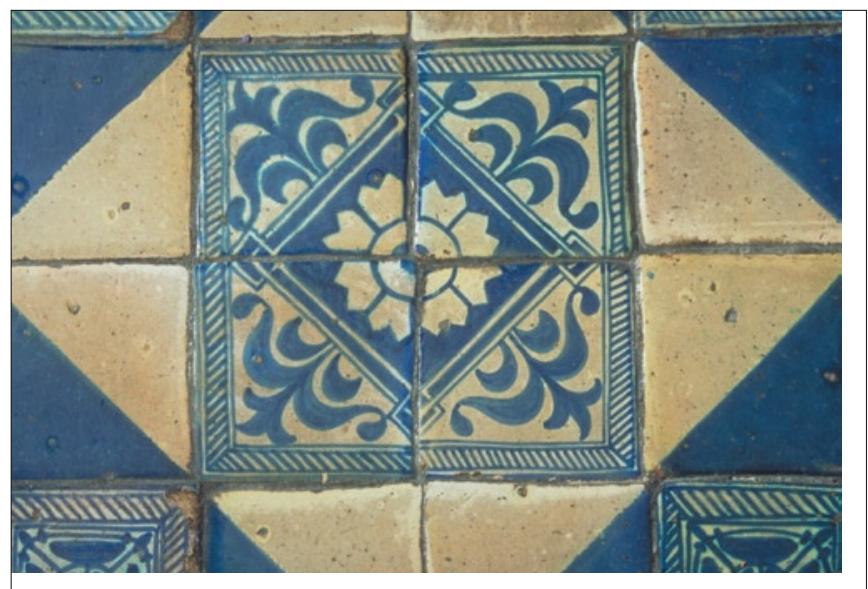

Figura 1a. Pavimento del Salón Dorado del Palau de la Genaralitat . Valencia . Siglo XV Detalle

Figure 1 a. Paving in the Golden Room of the Generalitat Palace . Valencia. 15th Century. Motive

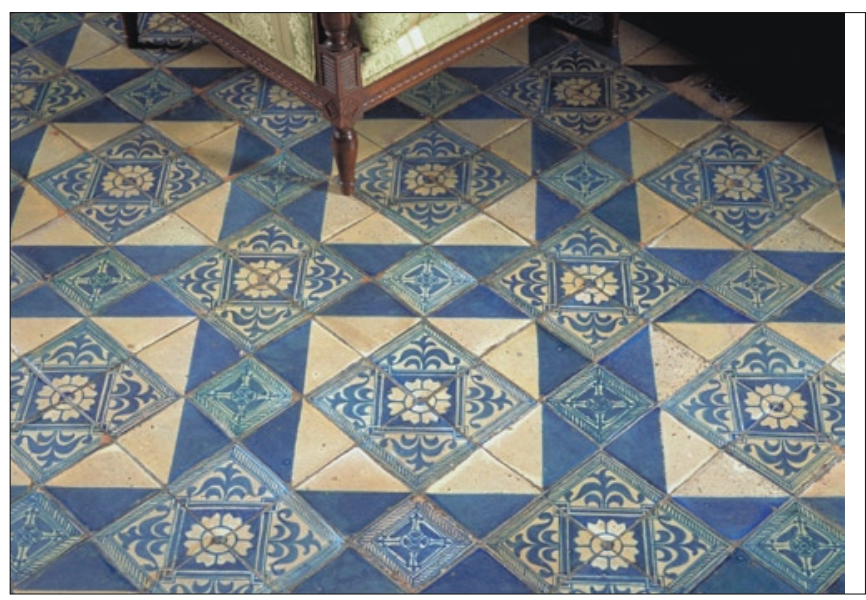

Figura 1b. Pavimento del Salón Dorado del Palau de la Genaralitat . Valencia . Siglo XV . Composición

Figure 1b. Paving in the Golden Room of the Generalitat Palace . Valencia . 15th Century . Motive room and with cuarto ornato tiles fitted in the centre and its vertices.

Cuarto ornato tiles in blue on white, with design arranged in diagonal and linkages on two adjacent sides. Symmetrical branch with tendrils, checked square at the base which contains a reserved rosette and piping for a border.

Complete pattern tiles with no linkage devices, arranged on two diagonal axes. Version of the Gothic rose (a four-petal flower with stylised stamens) with piping as a frame.

Models mentioned in "Cerámica del Levante Español, siglos medievales" Tome II, Azulejos-Alicatados, by M. González Martí (page 419, figure 577).

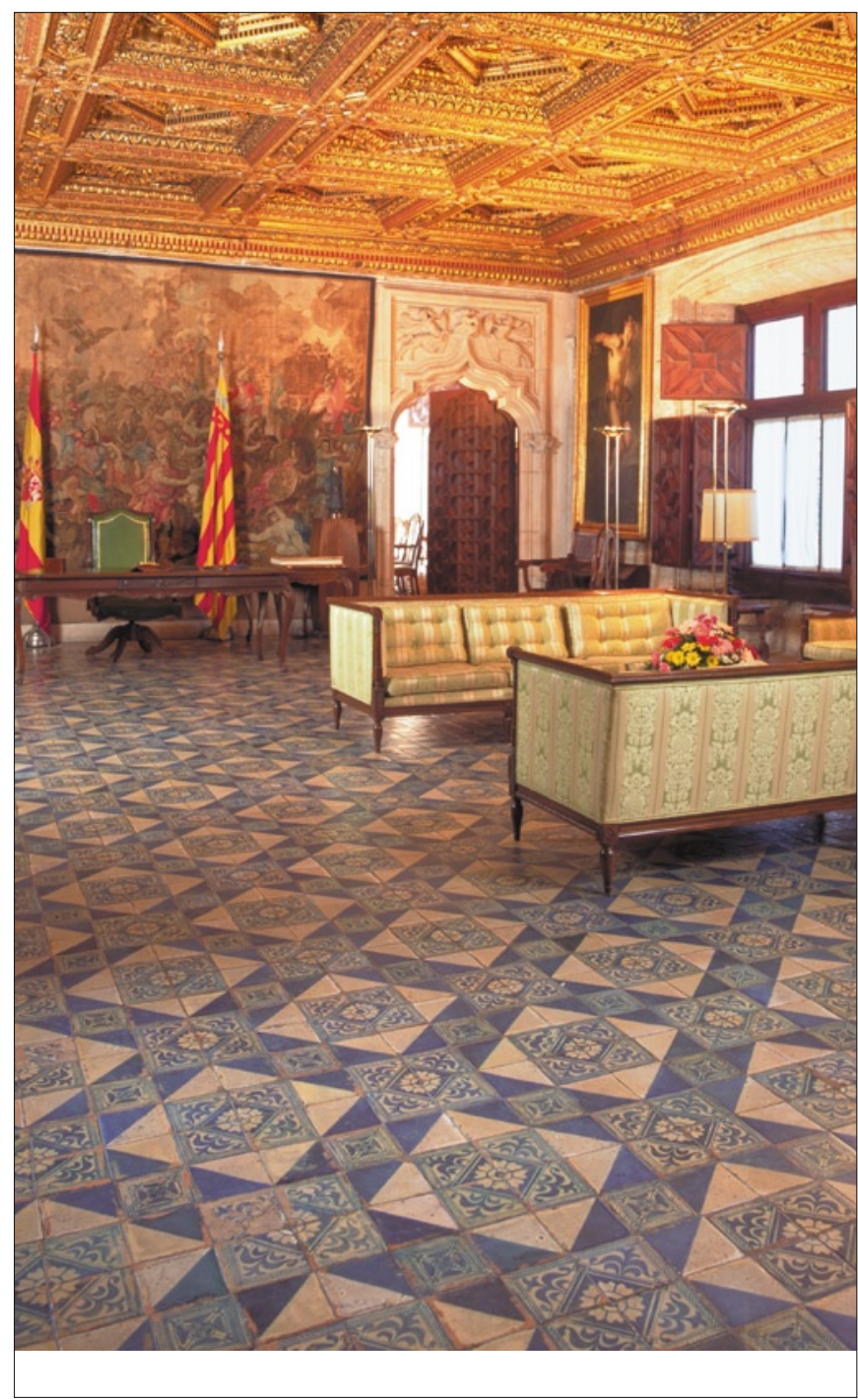

Figura 1c. Pavimento del Salón Dorado del Palau de la Genaralitat . Valencia . Siglo XV . Ambiente

Figure 1c. Paving in the Golden Room of the Generalitat Palace . Valencia . 15th Century . Ambient 


\section{2. Pavimento Cerámico en el Dormitorio del Palacio Ducal de Gandía}

Palacio formado por una serie de edificios que se construyen a partir del S. XIII. Perteneció a la familia Borja hasta 1740. En 1890 es adquirido por los jesuitas que abordan una profunda restauración con criterios historicistas. Fig. 2 a,b.

El pavimento del Dormitorio Ducal, de 4,12 X 5,25 m, está resuelto con una única baldosa cerámica de diseño en reserva, datable de 1.475-1.500.

Baldosa de mayólica, de formato $16 \times 16 \mathrm{~cm}$, decorada manualmente en azul cobalto sobre vidriado estannifero. Producción de Manises o en los hornos de Gandía.

Diseño en reserva con enlaces esquinares y en los centros de cada lado. Cuadrado inscrito con ondulación doble en los vértices que origina rosetas cruciformes partidas. Dos cadenas diagonales con eslabones alternos enlazan en el centro del diseño.

Los encadenados de eslabones blancos fueron modelos muy difundidos en el último tercio del S. XV.

Modelo reseñado en "Cerámica del Levante Español. Siglos Medievales". Tomo II, “Azulejos Alicatados", de M. González Martí (págs. 331 y 335, fíg. 439).

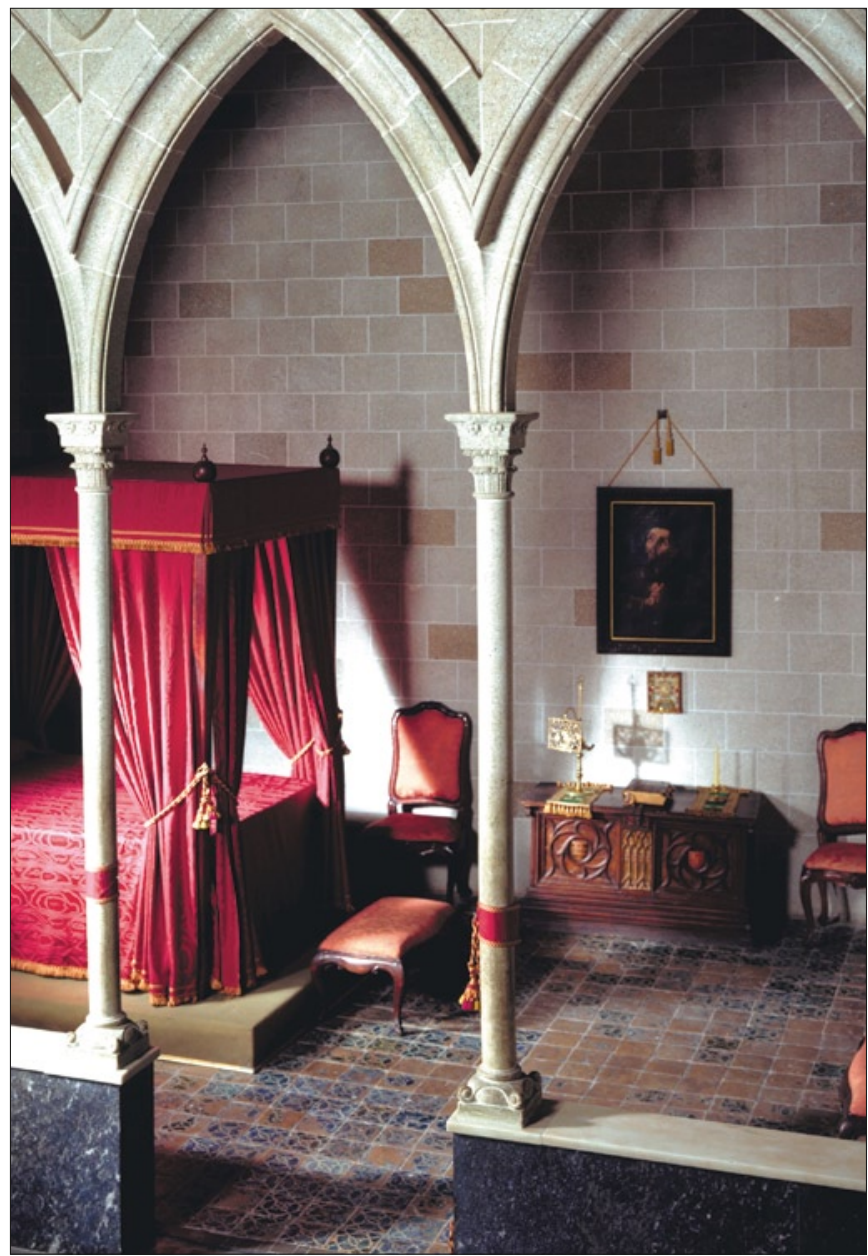

Figura 2a. Pavimento en el dormitorio del Palacio Ducal de Gandía Siglo XV . Ambiente

Figure 2 a. Ceramic paving in the bedroom of the Dukes' Palace in Gandía . 15th Century .Ambient
III.2. Ceramic paving in the beedroom of the Duke's palace in Gandia

A palace formed by a series of buildings constructed from the $13^{\text {th }}$ century on. This belonged to the Borgia family until 1740. In 1890 it was purchased by the Jesuits who set about an in-depth restoration with historicist criteria.

The paving of the Dukes' Bedroom, $4.12 \times 5.25$ in size, is formed with a single kind of ceramic tile with reserved design that can be dated back to $1.475-1.500$.

Maiolica tile, $16 \times 16$ in size, hand-decorated in cobalt blue on tin glaze. Made in Manises or in Gandía kilns.

Reserved design with linking patterns in the corners and centres of each side. A square traced with double wavy lines at the vertices leading into split cross-shaped rosettes. Two diagonal chains with alternate links join in the centre of the design.

Chains with white links were very widespread models in the last third of the $15^{\text {th }}$ century.

Model mentioned in "Cerámica del Levante Español, siglos medievales" Tome II, Azulejos-Alicatados, by M. González Martí (page 331 and 335, figure 439).

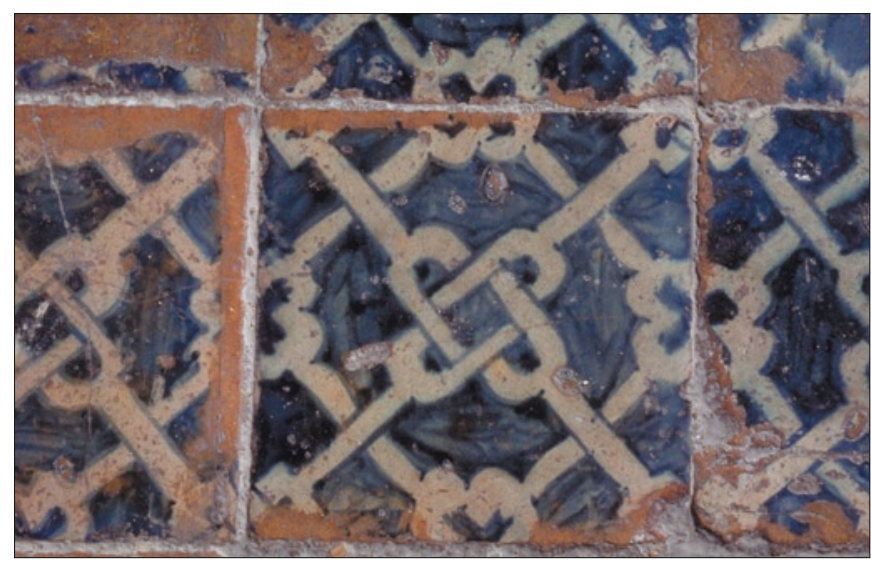

Figure $2 b$. Pavimento en el dormitorio del Palacio Ducal de Gandía. Siglo XV. Detalle

Figure 2b. Ceramic paving in the bedroom of the Dukes' Palace in Gandía . 15th Century. Motive 


\section{3. Arrimadero en el Atrio de la Iglesia del Colegio del Corpus Christi ( Valencia )}

Colegio fundado en 1583 por Juan de Ribera e iniciada su construcción en 1586, junto a la Universidad de Valencia, más conocido como Colegio del Patriarca. La iglesia, ubicada en el ala Oeste se construye entre 1590 y 1604 . (Figs. 3a,b,c,d).

Zócalo o arrimadero cerámico en el atrio, la nave y las capillas laterales, con modelos de inspiración serliana tardomanierista, con baldosas cerámicas de 1602-1608, atribuidas a Antonio Simón, ceramista que desarrolla su actividad en la ciudad de Valencia.

Baldosas de mayólica, de formato aprox. 14x14 cm, decoradas manualmente a partir del estarcido, a cinco tintas: dos tonos de azul cobalto, amarillo, naranja, verde y trazos de marrón manganeso. Perfiladas en azul.

El arrimadero tiene una estructura de paño central y bandas circundantes. El paño central se resuelve con un diseño de cuarto, con eje diagonal de simetría y enlaces en los cuatro lados y tres vértices. Las líneas paralelas forman una banda mixtilínea, con relleno de los espacios restantes con jaspes polícromos o verdosos. Las bandas mixtilíneas derivan del diseño textil y son quizás el recurso ornamental más perdurable de la azulejería valenciana (hasta mediados del S. XVIII).

Las bandas que circundan el paño central se resuelven con los diseños de la ova y la punta de diamante, que incluyen tarjas con enrollamiento. Diseños del repertorio de Sebastiano Serlio (Libro IV) de gran difusión en la azulejería.

Modelos reseñados en Cerámica Arquitectónica Valenciana. Los azulejos de serie (S. XVI-XVIII), de I. Vicente Pérez Guillén (págs 21-32, Vol. II)

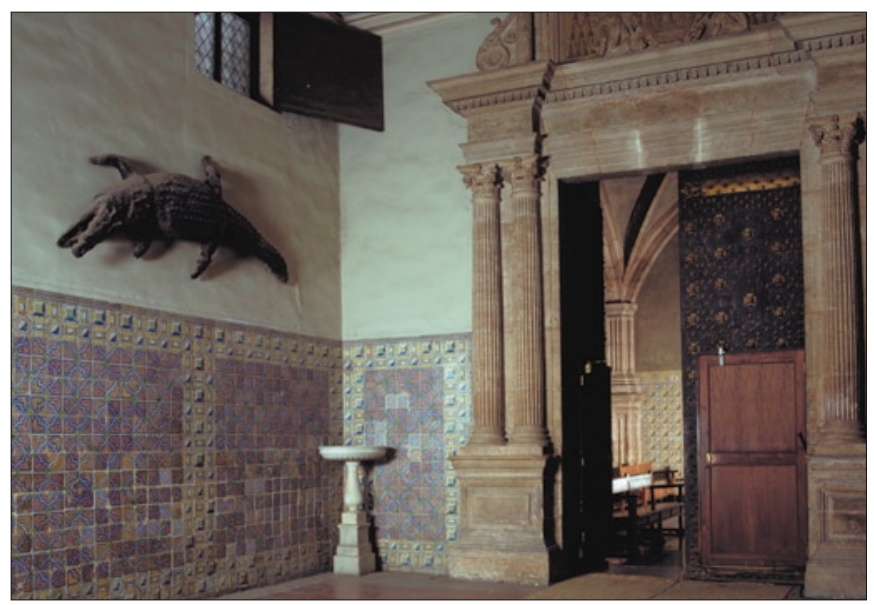

Figura 3a. Arrimadero en el Atrio de la Iglesia del Corpus Christi Valencia . Siglo XVI . Ambiente

Figure 3a. Wainscot in the atrium of the Corpus Christi College Church . Valencia. 16 th Century. Ambient

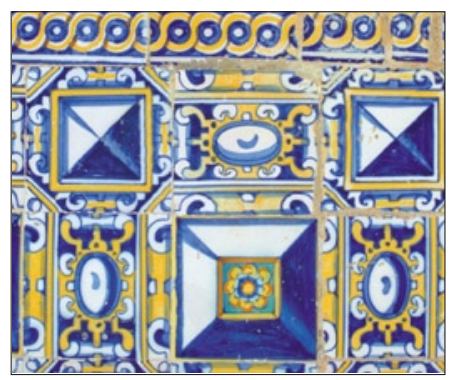

Figura 3b. Arrimadero en el Atrio de la Iglesia del Corpus Christi . Valencia . Siglo XVI . Detalle

Figure $3 b$. Wainscot in the atrium of the Corpus Christi College Church. Valencia. 16 th Century .Motive

\section{III.3 Wainscot in the atrium of the Corpus Christi College} Church (Valencia)

This was a school founded in 1583 by Juan de Ribera, whose building was started in 1586, beside the University of Valencia. Better known as the Colegio del Patriarca. The church, located in the west wing, was built between 1590 and 1604. (Figs. 3a,b,c,d).

Tiled wainscot or plinth in the atrium, nave and side chapels with Serlian late-mannerist inspiration models, consisting of ceramic tiles from 1602-1608, attributed to Antonio Simón, a ceramics craftsman who worked in the city of Valencia.

Maiolica tiles roughly $14 \times 14 \mathrm{~cm}$. in size, hand-decorated from a stencil, in five shades: two tones of cobalt blue, yellow, orange, green and traces of manganese brown. Edged in blue.

The wainscot has a structure with a central panel and outlying bands. The central panel is formed with a de cuarto design, with diagonal symmetrical axis and linkages at the four edges and three vertices. The parallel lines form a composite band, with the spaces left being filled in with polychrome or greenish jaspers. The composite bands stem from textile design and are perhaps the most enduring ornamental facet of Valencian tilework (until the mid $18^{\text {th }}$ century).

The bands which surround the central panel are formed with ova designs and punta de diamante patterns which include shields with scrolling. Designs from Sebastiano Serlio's repertoire (Book IV) very widely used in tile-making.

Models mentioned in Cerámica Arquitectónica Valenciana. The standard tiles $\left(16^{\text {th }}-18^{\text {th }}\right.$ centuries $)$ are from I. Vicente Pérez Guillén (pages 21-32, Vol. II).

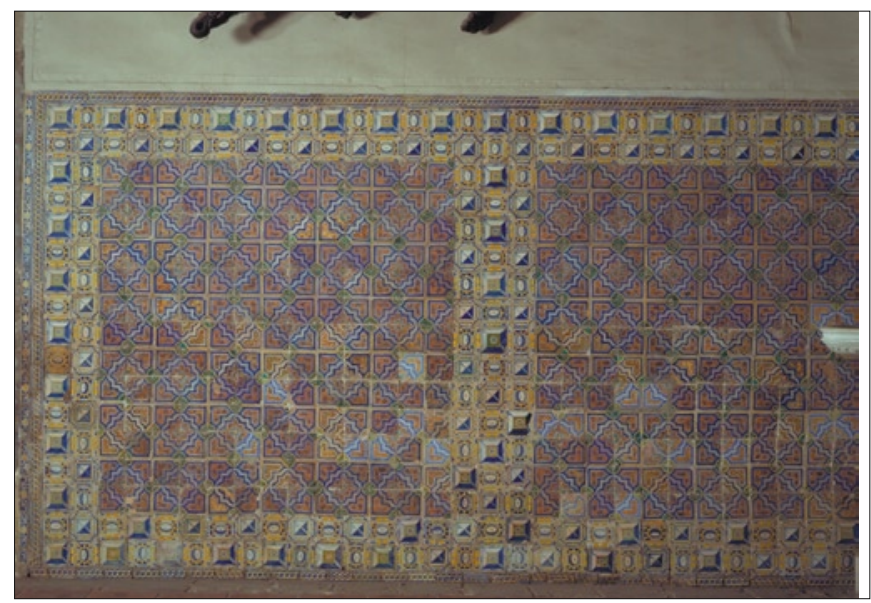

Figura 3c. Arrimadero en el Atrio de la Iglesia del Corpus Christi Valencia . Siglo XVI . Ambiente

Figure 3c. Wainscot in the atrium of the Corpus Christi College Church. Valencia. 16 th Century. Ambient

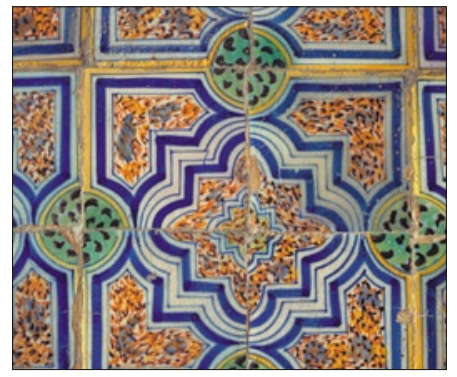

Figura $3 \mathrm{~d}$. Arrimadero en el Atrio de la Iglesia del Corpus Christi . Valencia . Siglo XVI . Detalle

Figure 3d. Wainscot in the atrium of the Corpus Christi College Church. Valencia. 16 th Century Motive 


\section{4. Arrimadero en la Iglesia de la Santa Cruz de} Valencia

Iglesia de estilo gótico del S. XIV (conservado en la bóveda del presbiterio) que se amplia en el S. XVII, con una renovación general en su interior datada de 1689. Figs. 4 a,b,c.

Se conserva azulejería del S. XVII en pilastras, muros y la capilla de la Comunión. Otros arrimaderos son del S. XVIII (capilla de la Purísima).

El arrimadero aquí referenciado se encuentra en la entrada, nave central y capillas. Data de principios de siglo XVII y reproduce una estructura de gusto gótico, con la cuadrícula a cartabón resuelta con el mitadat y dos modelos que encuentran gran difusión en su época.

Un diseño de cuarto en azul, amarillo, naranja y perfilado en azul sobre vidriado blanco, de formato $11,5 \times 11,5 \mathrm{~cm}$, con una estilización de lirios en diagonal.

Una baldosa de diseño completo de formato $11,5 \times 11,5 \mathrm{~cm}$, en amarillo limón, azul oscuro, amarillo y perfilados en azul y marrón. Es interesante porque resume en una sola pieza el diseño de cuarto de la flor de lis, como un antecedente de la práctica de rediseño del repertorio de cuarto que acontecerá con el cambio de formato, a mediados del s. XVIII.

Modelos reseñados en Cerámica Arquitectónica Valenciana. Los azulejos de serie (S. XVI-XVIII), de I. Vicente Pérez Guillén (págs 21-32, Vol. II)

\section{4 Wainscot in Santa Cruz Church in Valencia}

A $14^{\text {th }}$ century Gothic style church (preserved in the vault of the presbytery) which was extended in the $17^{\text {th }}$ century, with an overall renovation of its interior dating from 1689 . Figs. 4 a,b,c.

$17^{\text {th }}$ tiling kept in pilasters, walls and the Communion chapel. Other wainscots date from the $18^{\text {th }}$ century (chapel of the Virgin).

The wainscot mentioned here is found in the entrance, central nave and chapels. It dates back to the early $17^{\text {th }}$ century and reproduces a Gothic style structure, with the setsquare grid worked out with the mitadat and two models which were widely found at the time.

A de cuarto design in blue, yellow, orange and edged in blue on a white glaze, $11.5 \times 11.5 \mathrm{~cm}$. in size, with a diagonally set lily stylisation.

A complete pattern tile in 11.5 x $11.5 \mathrm{~cm}$. size, in lemon yellow, dark blue, yellow and edged in blue and brown. This is interesting because it sums up in a single piece the quarter fleur-de-lis design, as a precursor of the practice of redesigning the de cuarto repertoire which would occur with the change of format, in the mid $18^{\text {th }}$ century.

Models mentioned in Cerámica Arquitectónica Valenciana. The standard tiles $\left(16^{\text {th }}-18^{\text {th }}\right.$ centuries $)$ are from I. Vicente Pérez Guillén (pages 21-32, Vol. II).

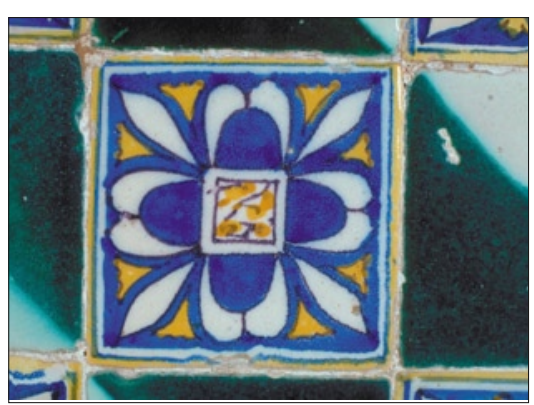

Figura 4a. Arrimadero en la Iglesia de la Santa Cruz. Valencia . Siglo XVII . Detalle

Figure 4a. Wainscot in Santa Cruz Church. Valencia. 17 th Century. Motive

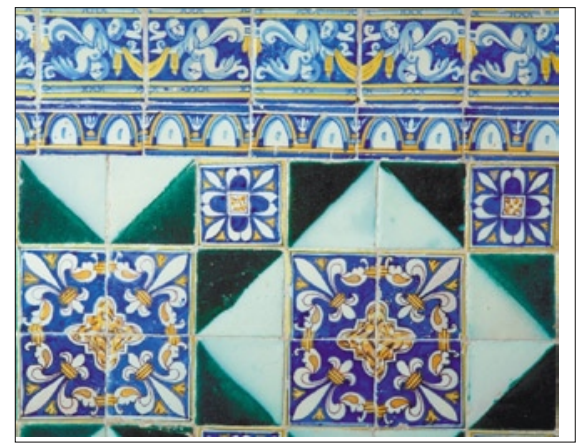

Figura 4b. Arrimadero en la Iglesia de la Santa Cruz . Valencia . Siglo XVII Composición

Figura 4b. Wainscot in Santa Cruz Church. Valencia. 17 th Century. Motive

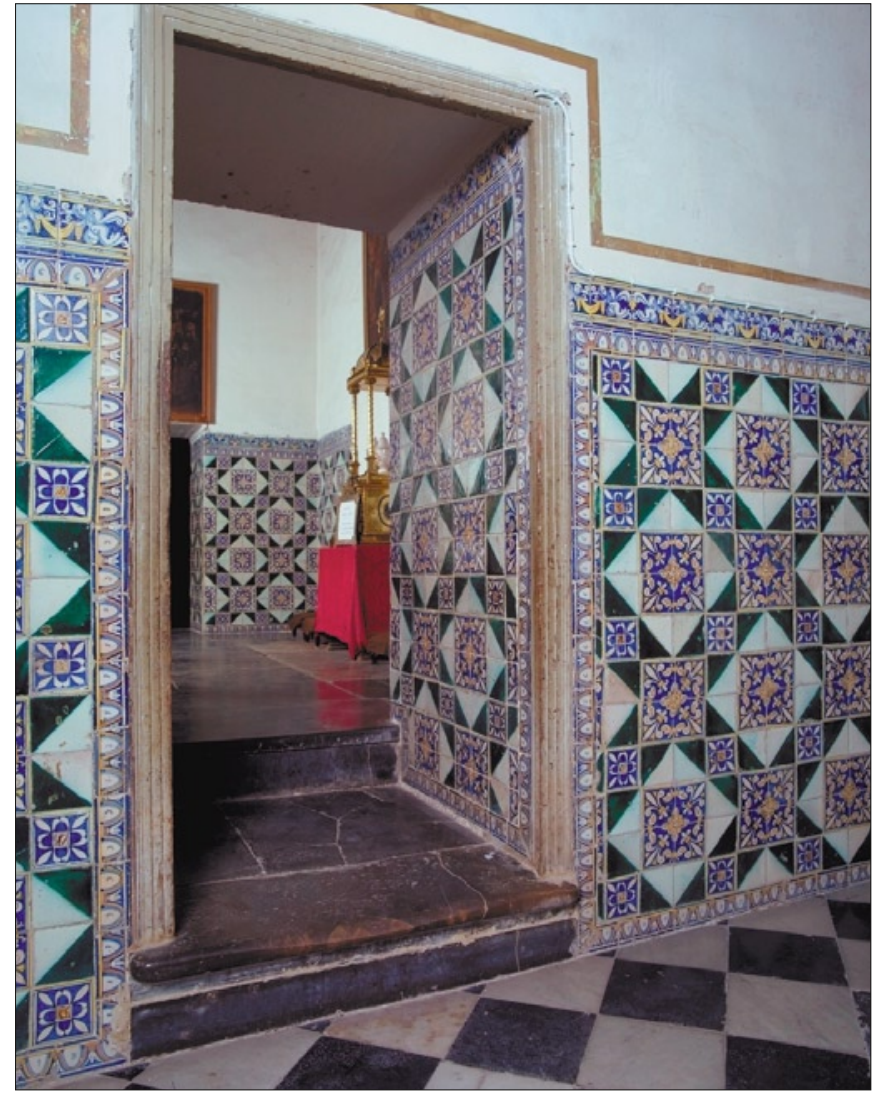

Figura 4c. Arrimadero en la Iglesia de la Santa Cruz . Valencia . Siglo XVII . Ambiente

Figure 4c. Wainscot in Santa Cruz Church . Valencia . 17 th Century. Ambient 


\section{5. Arrimadero en Portería del Convento de San José de Valencia}

Convento fundado en 1588 e instalado en la plaza del Portal Nuevo en 1609. La iglesia, de estilo barroco, es el único edificio primitivo ya que el resto fue derribado y reedificado recientemente. Fig. 5 a,b,c.

Los abundantes restos de azulejería del S. XVIII conservados han sido recolocados en el locutorio, sacristía, huerto y diversas dependencias del convento.

El conjunto reseñado debió formar parte de una solería aunque ha sido reinstalado como arrimadero, con cuerpo central y cenefa terminal.

Conjunto representativo del rococó cerámico valenciano.

Baldosas de mayólica, de formato 21,5 x 21,5 cm (palmo valenciano), decorados manualmente a partir de estarcido sobre vidriado de estaño. La decoración a partir del estarcido sobre vidriado de estaño. La policromía de la decoración incluye el amarillo, naranja, turquesa, morado, verde y perfilado con marrón de manganeso. Diseño de procedencia textil, ya presente en sedas francesas de 1720-1725; inspirado también en las decoraciones otomanas del S. XVI, a base de ristras de flores de ciruelo.

El diseño del motivo central es un rameado de a cuatro (cuatro piezas forman secuencia repetitiva), con enlaces en sus cuatro flancos y diversos elementos fitomorfos (hojas saz con perlarios, flores de ciruelo, pasionarias, lirios, peonias con zarcillos y cápsulas).

La cenefa superior está resuelta con un diseño con enlaces a dos lados opuestos. Dos bandas onduladas de trayectoria entrecruzada, una con cinta bicolor de bordes festonados y otra con hojas trilobuladas imbricadas, complementadas con un fino tallo de curvatura asimétrica.

Modelos reseñados en Cerámica Arquitectónica Valenciana. Los azulejos de serie (S. XVI-XVIII), de I. V. Pérez Guillen (Tomo II, cat. 714 págs. 257 y 281).

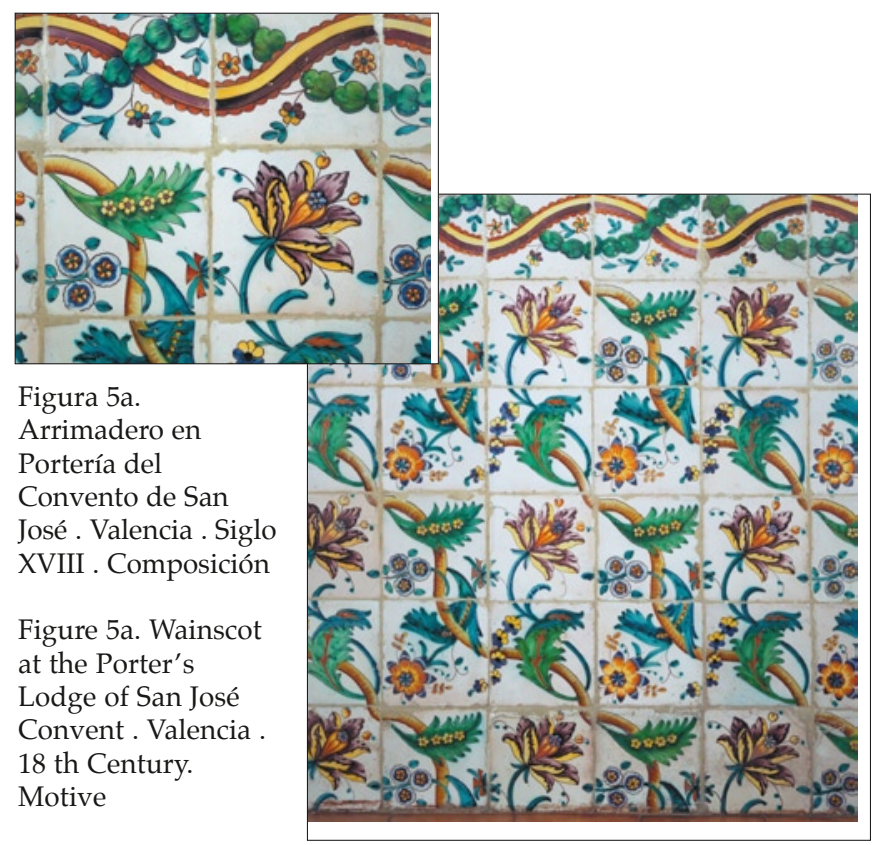

Figura 5a. Arrimadero en Portería del Convento de San José . Valencia . Siglo XVIII . Composición

Figure $5 \mathrm{~b}$. Wainscot at the Porter's Lodge of San José Convent. Valencia. 18 th Century. Motive

\section{III.5 Wainscot at the porter's lodge of San José Convent in} Valencia

The convent was founded in 1588 and installed in Portal Nuevo square in 1609. The baroque style church is the only original building now remaining, as the rest was demolished and recently rebuilt. Fig. 5 a,b,c.

The many remains of $18^{\text {th }}$ century tilework were refitted in the parlour, sacristy, garden and different rooms in the convent.

This particular group must have formed part of a pavement, though this has been refitted as an wainscot, with a central body and terminal frieze.

The group is representative of Valencian rococo ceramics.

These are maiolica tiles $21.5 \times 21.5 \mathrm{~cm}$. in size (the Valencian span) hand-decorated from a stencil on tin glaze. The polychromatic decoration is done from a stencil on tin glaze. This polychromatic decoration includes yellow, orange, turquoise, purple and green and is edged with manganese brown. The design has textile origins, already present in French silks from 1720-1725; also inspired in $16^{\text {th }}$ century Ottoman decoration, based on strings of plum tree blossom.

The pattern of the central motif is a rameado de a cuatro (four items forming a repetitive sequence) with linkages on its four sides and different plant-shaped elements (willow leaves with droplets, plum blossom, passionflowers, lilies, peonies with tendrils and capsules).

The upper frieze is formed with a pattern with linkages on two opposite sides. There are two wavy bands crossing each other, one with twin-colour tape with festooned borders and another with overlapping trilobate leaves, complemented with a fine asymmetrically curving stalk.

Models mentioned in Cerámica Arquitectónica Valenciana. The standard tiles $\left(16^{\text {th }}-18^{\text {th }}\right.$ centuries) are from I. V. Pérez Guillén (Tome II, cat. 714, pages 257 and 281).

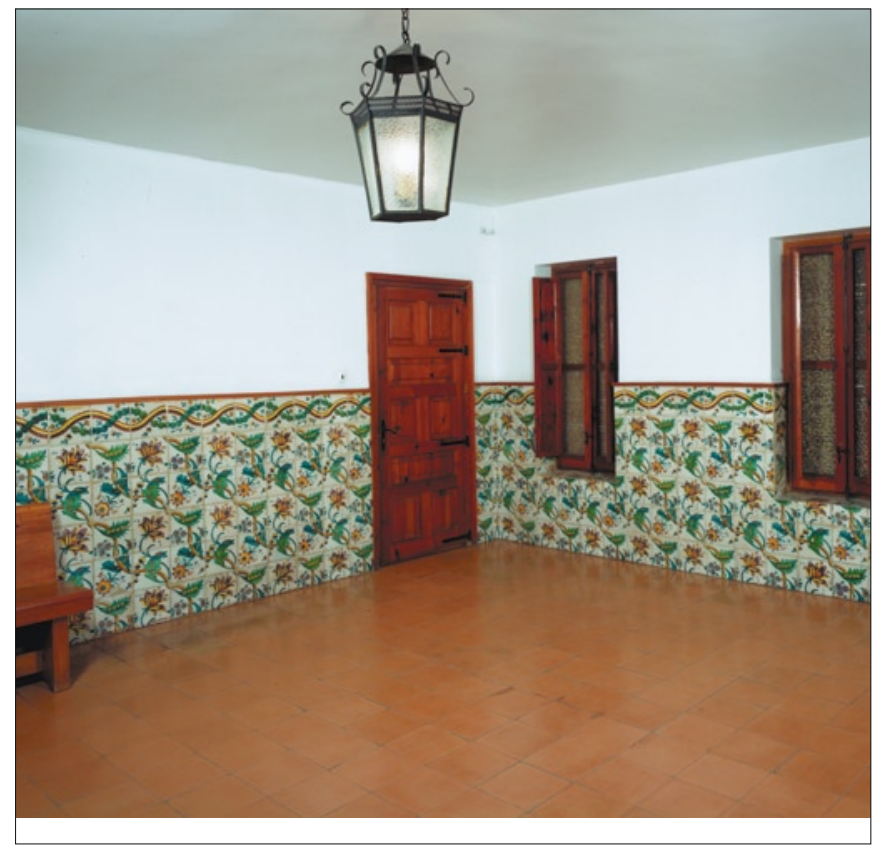

Figura 5c. Siglo 18 c Arrimadero en Portería del Convento de San José. Valencia . Siglo XVIII . Ambiente

Figure 5c. Siglo 18 c Wainscot at the Porter's Lodge of San José Convent . Valencia . 18 th Century. Ambient 


\section{6. Pavimento en el Palacio de la Marquesa de San} Joaquín (Castellón)

Pavimento cerámico seriado, compuesto y combinado, con una disposición central en forma de alfombra, en recibidor del primer piso, en el palacio de la Marquesa de San Joaquín, extendido sobre una superficie de 3,8 x 4,25 m. Figs. 6a,b.

Este Palacio, conocido como Casa del Barón de La Puebla, fue mandado construir por D. Juan Vallés, Sr. de la Serra d'en Garcerán y Barón de la Condesa. Ha tenido diferentes reformas, desconociéndose si los recubrimientos cerámicos han sufrido reubicaciones desde mediados del siglo XIX.

La baldosa cerámica objeto de rediseño forma conjunto con otro diseño de pieza única que compone rosetones de $a$ cuatro y reproduce una elipse achatada con grafismo verde procedente de un colofón sencillo de las artes gráficas. El pavimento se completa con una orla perimetral a la que siguen cuatro hiladas exteriores en el encuentro con los paramentos verticales, a modo de orlas complementarias y alternando filas de baldosas bizcochadas y baldosas decoradas con ramilletes de flores.

El diseño seleccionado se atribuye a la producción de Valencia u Onda de mediados del S. XIX, concretamente a la fábrica de Novella y Garcés.

Baldosa de mayólica, de formato 20,5 x 20,5 cm, con decoración azul cobalto monocroma sobre vidriado estannífero con dos intensidades de tinta, con raspados simulando nervaduras y sin perfilación.

Diseño de cuarto ornato según un eje diagonal de simetría, con una gran hoja de acanto abierta en su penca central y extendiendo dos alas de perfil curvo. El espacio residual se sombrea en oscuro hasta la arista de dos lados consecutivos.

Este modelo, con la estructura y posibilidades combinatorias del mitadat alcanzó una gran difusión en su época, por su simplicidad y efecto decorativo. Se fabricó con diferentes variantes y se exportó a la Habana y Montevideo.

Diseño documentado por el Prof. I. V. Pérez Guillén.

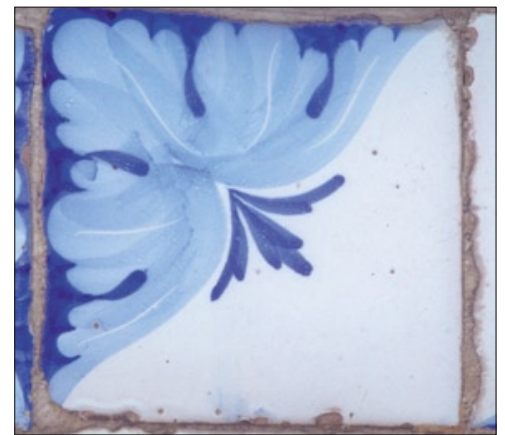

Figura 6a. Siglo 19. Pavimento en el Palacio de la Marquesa de san Joaquín . Castellón . Siglo XIX . Detalle

Figure 6a. Siglo 19. Paving at the Palace of the Marquise of San Joaquín. Castellón . 19 th Century Motive

\section{III.6 Paving at the palace of Marquise of San Joaquín} (Castellón)

Serialised composite and combined ceramic paving, with a central item in the form of a carpet, in the first floor hall at the palace of the Marquise of San Joaquín, covering a surface area of $3.8 \times 4.25$ m. Figs. $6 a$,b.

This palace, known as the "Casa del Barón de La Puebla", was built for Mr. Juan Vallés, Señor de la Serra d'en Garcerán y Barón de la Condesa. It has undergone different alterations, and it is not known if the location of the ceramic facings has been changed since the mid $19^{\text {th }}$ century.

The ceramic tiles now redesigned formed a ensemble with another design of a single tile which consists of a cuatro rosettes and reproduces a flattened ellipse with a green graphic item stemming from a simple colophon used in the graphic arts. The paving is completed with a peripheral border which is followed by four outer rows in the encounter with the vertical walls, like complementary borders and alternating rows of biscuit floor tiles and tiles decorated with posies of flowers.

The design selected is thought to have been created by mid-19 $9^{\text {th }}$ century Valencia or Onda makers, specifically at the Novella and Garcés factory.

Maiolica tiles, $20.5 \times 20.5 \mathrm{~cm}$. in size, with monochrome cobalt blue decoration over tin glaze with two intensities of ink, with rasping to look like ribbing and with no outlining.

Cuarto ornato design on a diagonal symmetric axis, like a large acanthus leaf open along its central rib and extending

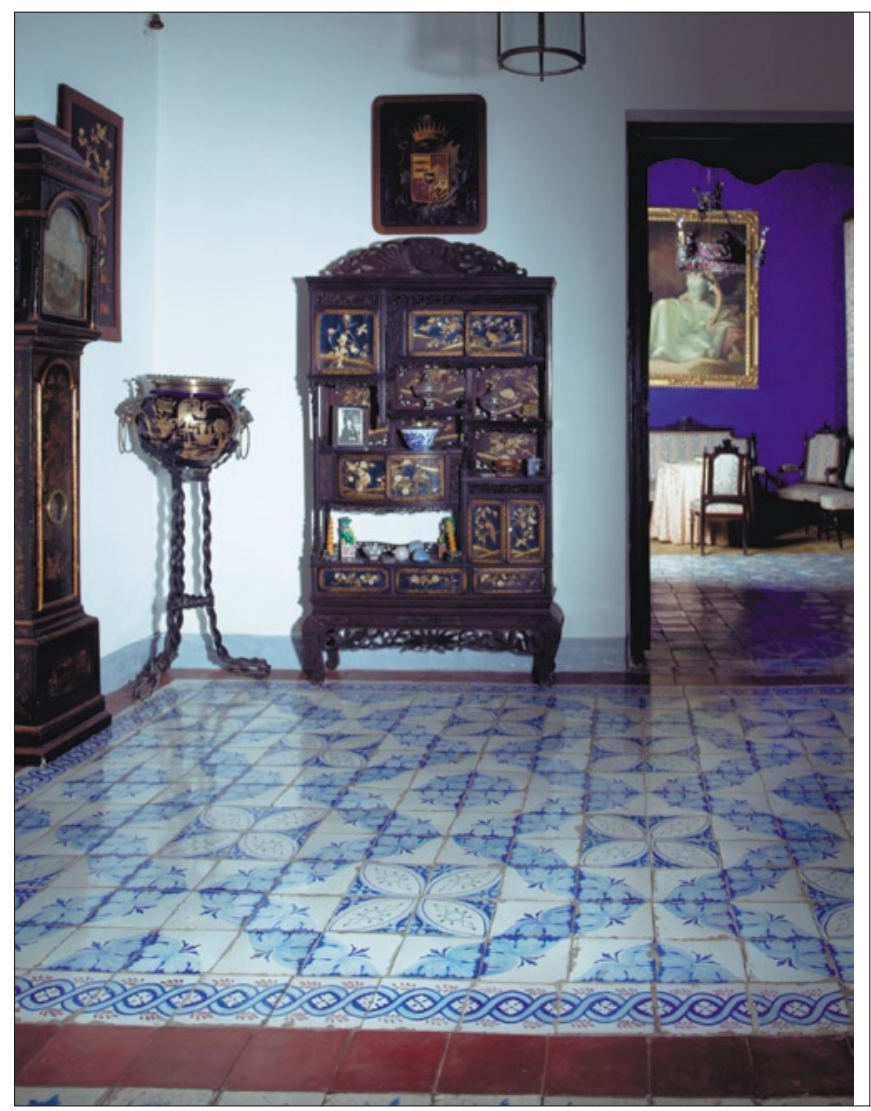

Figura 6b. Siglo 19. Pavimento en el Palacio de la Marquesa de san Joaquín . Castellón . Siglo XIX . Ambiente

Figure 6b. Siglo 19. Paving at the Palace of the Marquise of San Joaquín. Castellón 19 th Century Ambient 


\section{CONTEXTO HISTÓRICO Y ESTILÍSTICO}

La producción valenciana de cerámica arquitectónica y muy especialmente de baldosas constituye, globalmente, un fenómeno único en Europa, tanto desde la fabricación como desde la utilización de los recubrimientos cerámicos.

En dos etapas históricas alejadas 500 años, la cerámica valenciana alcanza una proyección internacional. La primera corresponde al periodo comprendido entre finales del siglo XIV y finales del siglo XV, cuando Paterna primero y Manises después, junto con los centros valencianos de Mislata, Alaquàs, Aldàia, Quart, Burjassot y Alfara alcanzan con la producción de mayólica azul y dorada un reconocimiento internacional, tal como expresa elocuentemente F. R. Francesc Eximenis, en el año 1412:

... Mas sobretot és la belleza de la obra de Manizes, daurada e maestrivolment pintada que ja tot lo mon ha enamorat, entant que lo papa e los cardenals e los prínceps del mon per special gràcia la requeren e estant maravellats que de terra se puixa fer obra així excel-lent e noble. *

* Pero sobre todo es la belleza de la obra de Manises , dorada y magistralmente pintada, que a todo el mundo ha enamorado , tanto , que el Papa, los cardenales y los príncipes del mundo por especial gracia la piden y están maravillados que del barro se pueda hacer obra tan excelente y noble.

Un vidriado estannífero de calidad, la alquimia de los lustres de pigmentos reducidos, la fusión del repertorio hispanomusulmán y la incorporación de la decoración gótica, junto con el poder político y comercial de la Corona de Aragón, serán los factores determinantes de la proyección internacional de nuestra cerámica, desde Italia hasta Alejandría, hacia Francia y el Reino Unido.

Cuando el Papa Valenciano Alejandro VI reforma las estancias vaticanas con baldosas valencianas en 1494 ya se ha producido un desfase estilístico respecto al repertorio renacentista que, desde Italia, se difunde por toda Europa. A partir de ese momento, la producción valenciana entra en crisis respecto a otras producciones peninsulares (Sevilla, Toledo, Cataluña y Portugal), aunque pronto incorpora la plena policromía y los repertorios de gran difusión en Europa a partir de la publicación de L'Architettura de Sebastiano Serlio. Durante el Siglo XVI, la azulejería valenciana está acotada al propio territorio, con un muy limitado repertorio de diseños que se producen de forma seriada en los formatos $14 \times 14 \mathrm{~cm}$ y $7,5 \times 14 \mathrm{~cm}$.

El escueto repertorio serliano se ejecuta con dos colores básicos, el azul cobalto y al amarillo de antimoniato de plomo, a los que, de forma muy secundaria, se añaden verdes, naranjas, morados y perfilados en azul o marrón oscuro de manganeso, todos ellos dentro de un contexto de gran homogeneidad en el cromatismo.

Esta etapa de declive se extiende hasta el siglo XVII, en lo que viene en denominarse la azulejería del barroco inicial. Sigue el contraste del azul oscuro con el amarillo, ahora ya no tan claro, y aparecen en el repertorio cartelas con enrollamientos y diferentes motivos vegetales, con una amplitud mayor que los diseños de la segunda mitad del Siglo XVI. Es constatable la influencia de la azulejería catalana, a su vez influida por la producción italiana, a partir de la cual llegan incluso diseños de origen otomano. Se da un predominio del repertorio vegetal, manteniendo una estilización rigurosa. Respecto al formato continua entre el $11,5 \times 11,5 \mathrm{~cm}$ y el $13,5 \times 13,5 \mathrm{~cm}$, los primeros con predominio hacia pavimentos y los segundos preferiblemente destinados a zócalos. Se da también una escueta producción de piezas cantoneras para zócalos. Esta etapa se cierra aproximadamente con la Guerra de Sucesión. two wings with curved profile. The remaining space is shaded in a dark tone up to the edge of two consecutive sides.

With the structure and combinatory possibilities of the mitadat, this model became a great success at its time, thanks to its simplicity and decorative effect. It was made with different variants and exported to Havana and Montevideo.

Design documented by Professor I.V. Pérez Guillén.

\section{HISTORICAL AND STYLISTIC CONTEXT}

The Valencian production of architectural ceramics and particularly of tiles is as a whole a unique phenomenon in Europe, both from the manufacturing standpoint and the use of ceramic facings.

In two historical ages 500 years apart, Valencian ceramics reached international fame. The first corresponds to the period between the late $14^{\text {th }}$ century and the end of the $15^{\text {th }}$ century, when first Paterna and then Manises, along with the Valencian towns of Mislata, Alaquàs, Aldàia, Quart, Burjassot and Alfara, attained international renown with the production of blue and gold maiolica, as was eloquently expressed by F. R. Francesc Eximenis, in 1412:

... Mas sobretot és la belleza de la obra de Manizes, daurada e maestrivolment pintada que ja tot lo mon ha enamorat, entant que lo papa e los cardenals e los princeps del mon per special gràcia la requeren e estant maravellats que de terra se puixa fer obra aixi excel-lent e noble.

* But above all it is the beauty of Manises craft, golden and masterly painted, which has made everyone fall in love with it, so much so that the Pope, the cardinals and the princes of the world ask for this by special request and are astounded that such an excellent and noble work can be made from mere clay.

A quality tin glaze, the alchemy of the reduced pigment lustres, the merging of the Hispano-Moresque ranges available and the incorporation of Gothic decoration, along with the political and commercial power of the Crown of Aragon were all factors which determined the international influence of our ceramics, from Italy to Alexandria, to France and England.

When the Valencian Pope Alexander VI refurbished the Vatican rooms with Valencian tiles in 1494 there had already been a stylistic drop behind in respect of the renaissance repertoire which spread all over Europe from Italy. From this time on, Valencian production went into a crisis as compared with other peninsular production (Seville, Toledo, Catalonia and Portugal) though it would soon incorporate full polychrome effects and the repertoires so widely found all over Europe from the publication of Sebastiano Serlio's $L^{\prime}$ Architettura. Over the $16^{\text {th }}$ century Valencian tile making was restricted to its own territory, with a very limited repertoire of designs which were mass produced in $14 \times 14 \mathrm{~cm}$. and $7.5 \times 14 \mathrm{~cm}$. size formats.

The meagre Serlian repertoire was made in two basic colours, cobalt blue and antimonious lead yellow, to which greens, oranges and purples were added in a very secondary sense, and outlines in blue or dark manganese brown, all of these within a context of great chromatic uniformity.

This stage of decline went on until the $17^{\text {th }}$ century, in what is known as the initial baroque tilework. The contrast of dark blue with yellow, now not so light, continued, and the range available started to include cartouches, with scrolling and different plant motifs, with a greater amplitude than the 
El cambio de formato, del 11,5 y $13,5 \mathrm{~cm}$ al $22-22,5 \mathrm{~cm}$ (palmo valenciano), y el inicio de la renovación estilística coinciden con la recuperación generalizada de la economía valenciana a partir de 1721 .

Hay que destacar el rediseño de una parte de los motivos de cuarto a baldosa entera, así como la revitalización progresiva de la decoración vegetal y la proliferación de bandas diagonales polícromas, así como los diseños con enlaces esquinares. A mediados del siglo XVIII aparece con inusitada fuerza la azulejería rococó, teniendo como protagonista la rocalla en sus diferentes variantes. Este periodo de plena recuperación de la cerámica arquitectónica valenciana se extiende desde 1.755 y 1.770, con la etiqueta estilística del rococó. Solamente en el último cuarto de siglo, las formas con rocalla coexisten con los nuevos diseños de estilo academicista. Las cenefas de tallos curvos, los diferentes tipos de cintas, las cenefas festonadas, los azulejos con bordes decorados y la gran familia de los rameados constituyen el máximo exponente de la azulejería rococó. Todavía en este periodo la producción valenciana va destinada prioritariamente al consumo propio, con influencias en el exterior de la Comunidad (Murcia y los territorios limítrofes del Oeste) y exportaciones puntuales al norte de África y a otros territorios de la Península.

Concluye así el siglo XVIII con una etapa rica en repertorios y de la que, por otra parte, queda el mayor patrimonio de cerámica arquitectónica valenciana todavía en su lugar de origen, especialmente en la arquitectura religiosa. Se da paso a la azulejería clasicista, imperio y pompeyana que da entrada al siglo XIX. Aparece el diseño de dibujo completo con un amplísimo repertorio de flores, animales y objetos varios, así como representación de la figura humana, el amplísimo repertorio Biedermeier clasicista y el inicio de los diferentes eclecticismos e historicismos, que darán paso a la producción industrial.

Tras algunos primeros intentos por innovar la actividad cerámica, será a partir de mediados del siglo XIX cuando se desencadenen acontecimientos que lleven por tanto a la fabricación de nuevos productos como a la introducción de innovaciones técnicas, que permitan un aumento considerable de la producción y un abaratamiento del producto. En el primer caso, hay que citar la fábrica de Azulejos Nolla como la gran innovación cerámica en estas tierras, siguiendo el modelo de la producción inglesa de la época. En el segundo aspecto, se introduce primero el prensado mecánico del barro y después el prensado en semiseco, así como la decoración a trepa.

A finales del siglo XIX el núcleo principal de producción se traslada desde Valencia a Onda, quedando como producciones secundarias las de Manises y Alcora. Al mismo tiempo que las tierras castellonenses toman el relevo de la innovación tecnológica y la producción a gran escala, asistimos a una recuperación de la proyección internacional de la cerámica valenciana, ahora exclusivamente de la mano de la baldosa cerámica.

Se asiste a una trayectoria imparable de crecimiento de la producción y del consumo, con una clarísima repercusión exterior durante la Primera Guerra Mundial, con exportaciones tanto a países de la cuenca mediterránea como a Sudamérica.

Los recubrimientos cerámicos recuperaran su vocación arquitectónica tanto en la edificación de autor como en la vernácula, hasta configurar un fenómeno de popularización que se extiende hasta la Guerra Civil y que solamente es compartido por la arquitectura portuguesa.

Las baldosas cerámicas seleccionadas para este proyecto de rediseño pretenden ser representativas de las grandes etapas de la evolución de la cerámica arquitectónica valenciana, designs of the second half of the $16^{\text {th }}$ century. One can appreciate the influence of Catalan tile-making, in turn influenced by Italian production, from which designs of even Ottoman origin came. There was a prevalence of plant themes, keeping to strict stylisation. As regards the continuous format between the $11.5 \times 11.5 \mathrm{~cm}$. and $13.5 \times 13.5 \mathrm{~cm}$., the former were more extensively used for pavings and the latter preferably for plinths. There was also a scanty production of edge pieces for plinths or skirting sections. This stage came to an end at roughly the time of the War of Succession.

The change in format, from 11.5 and $13.5 \mathrm{~cm}$. to $22-22.5 \mathrm{~cm}$. (the Valencian span) and the start of stylistic renewal coincided with the general recovery of the Valencian economy from 1721.

One should stress the redesign of part of the quarter motifs to full tile patterns, as well as the progressive revitalisation of plant decoration and the proliferation of polychrome diagonal bands, as well as the designs with corner linkages. Half way through the $18^{\text {th }}$ century rococo tile making came forward with great inertia, with the rocaille in its different variants as its star subject. This period of full recovery of Valencian architectural ceramics lasted from 1755 to 1770, with the stylistic label of the rococo. Only in the last quarter of the century were the forms with rocaille seen to cohabit with the new academic style designs. Friezes with curved stalks, different types of tapes, festooned borders, tiles with decorated edges and the great family of branch structures all form the maximum exponent of rococo tile-making. In this period Valencian production was still mainly channelled towards its own consumption, with influences outside the Community (Murcia and bordering areas to the West) and isolated exports to the North of Africa and other parts of the Peninsula.

The $18^{\text {th }}$ century thus ends as an age with many and varied repertoires of which the greatest heritage of Valencian architectural ceramics still remained in its place of origin, especially as regards religious architecture. This goes on to make way for the classicist, imperial and Pompeiian architecture which opens the $19^{\text {th }}$ century. The full picture design appears with an extremely wide range of flowers, animals and different objects, as well as the representation of the human figure, the very wide classicist Biedermeier repertoire, and the birth of different eclecticisms and historicisms, which would lead into industrial production.

After certain early attempts to bring innovation to the ceramic business, it would be from the mid- $19^{\text {th }}$ century on that events leading both to the manufacture of new products and the introduction of technical innovations began to take place, allowing a considerable rise in production and cheaper products. In the first case, Nolla must be mentioned as the great ceramics innovation in our land, going along with the model of the English production of the time. In the second aspect, first mechanical clay pressing and then semi-dry pressing were introduced, as well as trepa stencil decoration.

In the late $19^{\text {th }}$ century the main production centre shifted from Valencia to Onda, leaving Manises and Alcora as secondary production areas. At the same time as the Castellón area took over in technological innovation and large-scale production, there was also a recovery of the international influence of Valencian ceramics, now exclusively in the form of ceramic tiles.

An unstoppable surge of growth in production and consumption was seen, with clear foreign repercussions during 
desde el siglo XV hasta finales del XIX. Selección basada también en la representatividad de los diseños en el contexto de su época y en la difusión que tuvieron.

\section{V.CONTEXTO TECNOLÓGICO}

\section{Antecedentes}

Bajo dominio político musulmán, la cerámica valenciana debió compartir la técnica y el repertorio difundidos en la península desde el siglo VIII por el Islam, siendo las principales innovaciones tecnológicas: la incorporación del vidriado opaco de estaño; la paleta de color aportada por los óxidos de cobalto, cobre, hierro y manganeso; la cocción estandarizada en el horno cilíndrico, conocido como horno árabe o moruno; y, muy especialmente, la decoración a baja temperatura con lustres de pigmentos reducidos; sin olvidar el inmenso repertorio aportado por el Arte Islámico y la decidida vocación arquitectónica bajo su amparo, y las técnicas del alicatado o de la cuerda seca.

Pocos vestigios han quedado en tierras valencianas de la cerámica arquitectónica bajo dominio musulmán. Una fuente de aliceres, alguna placa mortuoria, baldosas de diferente procedencia y un relativamente amplio legado de cerámica de contenedor.

Se sabe que el núcleo de Paterna compitió con su cerámica estannífera verde y morado con la cualificada producción de Muel y Teruel. El influjo entre centros alfareros debió ser intenso desde la época califal. Sin embargo, el viento de los tiempos y la dominación cristiana desde la reconquista de Valencia, diluyen lo que debió ser un salto cualitativo de considerables dimensiones, el paso de una cerámica no vidriada a otra que incorporó primero la cubierta de plomo y el vidriado estannífero después.

\section{1 La etapa medieval}

Tal vez bajo una consideración romántica de los aconteceres históricos, o quizás infravalorando la capacidad comercial de las tierras valencianas bajo dominio musulmán, suele aparecer en la bibliografía la familia Boïl, primero embajadores de la Corona de Aragón y después como señores de Manises, con una gran influencia política, como elemento desencadenante del proceso que llevará a la proyección internacional de la cerámica vidriada valenciana a partir de las postrimerías del siglo XIV. En todo caso, se empieza a tener documentación escrita de esa época (que no de la anterior) y, dado que la historia la escriben los vencedores, esa proyección internacional está vinculada a la expansión comercial de la corona de Aragón.

Se describe, con cierto detalle el panorama tecnológico por cuanto, sin apenas variaciones fundamentales, se extiende hasta bien entrado el siglo XIX. La esquematización de ese panorama no excluye la existencia de variaciones, en ocasiones con una gran repercusión en el producto final.

La cerámica del núcleo de Valencia se nutrirá esencialmente de arcillas calcáreas y ferruginosas de los depósitos de Quart y Aldàia. Concretamente, los centros de Paterna y Manises tienen una similar composición de las pastas, con un contenido de Ca situado un poco por debajo del $20 \%$ en el caso de Paterna y ligeramente superior a ese porcentaje en el caso de Manises. El hierro se mantiene entre el 3 y el $6 \%$ en el caso de Paterna y entre el 2 y el $5 \%$ en el de Manises ${ }^{1}$.

M. González Martí aporta que se realizaban mezclas de 9 the First World War, exporting both to countries in the Mediterranean basin and South America.

Ceramic facings recovered their architectural vocation both in known architects' creations and vernacular building, to the extent of constituting a popularisation phenomenon which went on until the Civil War and which was only shared by Portuguese architecture.

The ceramic tiles selected for this redesign project are intended to be representative of the important stages in the evolution of Valencian architectural ceramics, from the $15^{\text {th }}$ to the late $19^{\text {th }}$ century. The selection was also based on the representativeness of the designs in the context of their time and on how widely distributed these were.

\section{TECHNOLOGICAL CONTEXT}

\section{Background}

Under Arab political rule, Valencian ceramics must have shared the technique and repertoire spread over the peninsula from the $8^{\text {th }}$ century by Islam, the main technological innovations being: the incorporation of opaque tin glazing; the colour palette meant by oxides of cobalt, copper, iron and manganese; standardised firing in the cylindrical kiln, known as the Arab or Moorish kiln; and very specially, decoration at low temperatures with reduced lustres; not forgetting the immense repertoire contributed by Islamic Art and the clear architectural facet to this, as well as the tile cutting or cuerda seca techniques.

In Valencia there are few remains of the architectural ceramics created under Muslim rule: an alizar fountain skirting, certain mortuary plaques, floor tiles of different origin and a fairly wide legacy of recipient ceramics.

We know that Paterna competed with its green and purple tin ceramics with Muel and Teruel's qualified production. The influence between pottery centres must have been intense from the caliphate period. Nevertheless, the passing of time and Christian domination from the reconquest of Valencia dilute what must have been a qualitative leap of considerable size, the shift from a non-glazed ceramics to a craft which incorporated first transparent lead coating and later tin glaze.

\section{V.1 .The medieval age}

Perhaps from a romantic consideration of historical events, or perhaps through underestimating the commercial capacity of Valencian lands under Muslim rule, the Boil family tends to crop up in bibliographies, first as ambassadors of the Crown of Aragon and later as lords of Manises, with great political influence, through its involvement in triggering off the process that would lead to the international influence of Valencian glazed ceramics from the late $14^{\text {th }}$ century. In any event, we begin to have written documents on this age (but not on the previous one) and given that history is written by the victors, this international influence is linked to the commercial expansion of the crown of Aragon.

Here we shall describe the technological panorama in certain detail since this goes on with hardly any basic variations until well into the $19^{\text {th }}$ century. The schematic view of this panorama does not exclude the existence of variations, sometimes with significant repercussions on the final product.

The ceramics made in the centre of Valencia essentially 
partes de arcilla y 1 de creta. Otras fuentes indican que se llegaron a utilizar arcillas de cocción blanca de Llíria, especialmente para la confección de engobes.

La preparación de las arcillas para la conformación en estado plástico contemplaba primero la reducción de tamaño en la era, el tamizado (garbell), los depósitos con agua en balsas (balsot) incluyendo el último mezclado de la dispersión acuosa, un último proceso de sedimentación en una segunda balsa, formando estratos de arcilla de un espesor no superior a $15 \mathrm{~cm}$, la extracción de las tortas de arcillas (pellas) y el secado sobre enlucidos de yeso para la conformación al torno de la cerámica de contenedor. Tanto para la baldosa como para otros tipos de cerámica, las pellas debían tratarse mecánicamente para eliminar el aire ocluso.

En cuanto a la conformación en estado plástico, a las baldosas cerámicas se les daba forma mediante moldes de madera (graelles) con dimensiones normalizadas. Tras un primer secado natural, en algunos casos y para obtener una correcta desaireación de las piezas ( hoy se diría una mejor compactación), se procedía a la estampación de las baldosas en mesas (morberes) mediante palas (amauraores), estando documentado el oficio de estampador. Seguía a esa estampación la redefinición del formato en crudo, con el uso de plantillas y corte manual. Daba como resultado una pieza de geometría regular cortada en bisel con la cara vista de mayor superficie que el reverso, para facilitar el asentamiento de las baldosas a junta cerrada. Este proceso todavía está vigente en los alfares del norte de África.

A un secado natural seguía el proceso de cocción en el horno árabe, cilindro vertical de 2-5 m de diámetro y $5 \mathrm{~m}$ de altura, cerrado en su parte superior por una bóveda denominada alcobe, con dos cámaras comunicadas por toberas, siendo la inferior (llar) la dedicada a la cocción del bizcocho, el fritado de vidriados y la combustión de la leña (los vidriados se situaban en la parte elevada de esa primera cámara, denominada sachén, junto al frontó). La parte superior albergaba bizcocho en los laterales y en su parte superior, para proteger la cerámica vidriada en su centro. Diferentes orificios en el alcobe permitían controlar tanto el tiro como la atmósfera del horno. El orificio central recibía el nombre de allule y servía también para extraer muestras de esmaltes durante la cocción. Según investigaciones arqueométricas, los productos recibían temperaturas máximas medias de $1.000^{\circ}$, aunque en algunas muestras analizadas de la producción de Paterna se detectan cocciones incluso por encima de $1.100^{\circ}$.

La cocción de las baldosas esmaltadas se realizaba en el centro de la cámara superior, protegidas por bizcocho dispuesto en su contorno. La disposición radial mediante hiladas de piezas de ladrillo denominadas ferracons formando tapices (emplanillà), soportados a su vez por alcaides que sustentaban las baldosas, junto con otros elementos de soporte y distribución del producto esmaltado (llongots, morrells,...), dan idea de la complejidad de distribución de las baldosas cerámicas en el horno, tanto para permitir la libre circulación de los productos de la combustión, como para evitar el contacto entre piezas. Se desconoce si la desaparición de los trébedes (trípodes colocados encima de la superficie vidriada para soportar la baldosa siguiente, que dejaban tres marcas sobre el producto cocido) obedece a la colocación en vertical de las piezas, tal como está documentado a partir del siglo XIX (con la utilización de cajas refractarias de protección y colomins de barro para separar unas piezas de otras). En muchas muestras del siglo XV ya no se observan los tres puntos dejados por el contacto del trébede con el vidriado.

Merece una atención especial la elaboración del vidriado used the limy and iron-containing clays of the deposits in Quart and Aldàia. Specifically, the bodies coming from Paterna and Manises had a similar composition, with a Ca content slightly under $20 \%$ in the case of Paterna and slightly over this proportion in the case of Manises. The iron remains at from 3 to $6 \%$ in the case of Paterna and from 2 and 5\% in that of Manises. ${ }^{1}$

M. González Martí states that mixtures of 9 parts of clay and 1 of chalk were made. Other sources indicate that white firing clays from Lliria were used, especially for making engobes.

The preparation of clays for forming in a plastic state involved first their size reduction on the bed, sieving (garbell), deposits with water in tanks (balsot) including the last mixing of the water dispersion, a last sedimentation process in a second tank, forming strata of clay of a thickness not over $15 \mathrm{~cm}$., the extraction of clay cakes (pellas) and the drying on plaster sheets for wheel throwing of recipient ceramics. Both for tiles and for other types of ceramics, the cakes had to be mechanically treated to remove any trapped air.

As regards forming in a plastic state, ceramic tiles were given shape by means of wooden moulds (graelles) with standard sizes. After a first natural drying, in some cases, and to ensure proper deaereation of the items (today we would call this a better compaction) they proceeded to press-form the tiles on tables (morberes) by means of shovels (amauradores) with the job of press-former being documented. This pressforming was followed by the redefinition of the format in raw clay, with the use of stencils and manual cutting. The result of this was a piece with regular geometry, bevel cut, with the exposed side having a larger surface area than the back, in order to facilitate fitting the tiles with closed joints. This process is still in use in pottery workshops in North Africa.

After natural drying came the process of firing in the Arab kiln, a vertical cylinder $2-5 \mathrm{~m}$. in diameter and $5 \mathrm{~m}$. high, closed off at the top by a dome known as alcobe, with two chambers communicating by pipes, the lower one (llar) being used for firing the biscuit, fritting glazes and the combustion of the wood (the glazes were put at the top of this first chamber, known as sachén, beside the frontó). The top part was filled with biscuit at the sides and at the top, to protect the glazed ceramics in the centre. Different holes in the alcobe allowed both the air head and the atmosphere of the kiln to be controlled. The central hole was known as allule and was also used for taking out samples of enamels during firing. According to archeometric research, the products were subjected to average maximum temperatures of $1.000^{\circ} \mathrm{C}$, though in some samples analysed of Paterna production, firings of as much as $1.100^{\circ} \mathrm{C}$ and higher were detected.

The firing of enamelled tiles was performed in the centre of the upper chamber, protected by biscuit laid out around this. The radial layout by means of rows of pieces of brick known as ferracons forming mats (emplanillà) supported in turn by alcaides which held the tiles, along with other items for support and distribution of the enamelled product (llongots, morrells...) gives an idea of how complex the distribution of the ceramic tiles in the kiln was, both to allow free circulation of the products of the combustion and to prevent the pieces from touching each other. We do not know if the disappearance of trébedes (tripods placed on top of the glazed surface to support the following tile, which left three marks on the fired product) is due to placing the parts vertically, as documented from the $19^{\text {th }}$ century (with the use of refractory 
blanco de estaño. La primigenia cerámica vidriada hispanomusulmana recurría al bisilicato de plomo como frita base de todos sus vidriados, obtenido a partir de la galena (sulfuro de plomo) y arena silícea. Estos vidriados se coloreaban en masa para obtener la paleta básica utilizada en los alicatados: el blanco añadiendo un porcentaje reducido de opacificante $\left(\mathrm{SnO}_{2}\right)$; el azul, con o sin opacificante, a partir del $\mathrm{CoO}$ (açafre); el turquesa a partir del $\mathrm{CuO}$ sobre una composición de frita alcalina y escasa o nula presencia de plomo; el melado obtenido con el óxido de hierro diluido en el silicato de plomo; el verde a partir del $\mathrm{CuO}$ en base púmblica; el marrón/violáceo a partir del $\mathrm{MnO}_{2}$ y vidriados negros con una fuerte aportación de manganeso, hierro y cobalto sobre una frita base.

Los vidriados y colores amarillos están ausentes hasta el siglo XVI cuando se incorporan desde Italia, en base a una composición de antimoniato de plomo.

Esta escueta pero suficiente paleta de vidriados y colores presentes en la cerámica hispanomusulmana quedará reducida, en el caso de las baldosas cerámicas valencianas medievales, a la utilización de un único vidriado base (el bisilicato de plomo opacificado con estaño) y, excepcionalmente, el mismo vidriado sin opacificar con función de cubierta.

De la primigenia utilización directa de la galena se pasa a trabajar directamente con el plomo metálico que se somete a un proceso de oxidación en horno de reverbero, removiendo el plomo con una paleta (dragó) hasta obtener la completa oxidación ( $\mathrm{PbO}$ ó $\mathrm{Pb}_{3} \mathrm{O}_{4}$ ). El litargirio o mínio, denominado acercó, se mezclaba cuidadosamente con arena silícea y sal marina, y se fritaba conjuntamente con el estaño o separadamente de él, en recipientes depositados en el sachén del horno, existiendo la dualidad de preparar la frita base y mezclarla después con la calcina obtenida a partir del fritado del plomo y estaño, o incorporar directamente el estaño en la frita base. A diferencia de la mayólica italiana posterior, no se aporta fósforo a la composición a través de materia orgánica (como es el caso del poso de vino incorporado en el marzacotto).

A la operación de fritado seguía una trituración y una molienda, en ocasiones mediante muelas troncocónicas de piedra movidas con tracción animal, hasta conseguir la dispersión acuosa del esmalte a la granulometría adecuada para su correcta aplicación sobre el bizcocho.

El plomo era importado desde Venecia, normalmente de procedencia alemana, mientras que el estaño procedía de los Países Bajos y de Inglaterra. A lo largo de la historia, ambos productos fueron un problema para la producción cerámica valenciana $y$, muy especialmente, el estaño, obtenido a partir de la casiterita, por su alto precio y por los aranceles y dificultades que se presentaban para su importación.

Según los estudios arqueométricos el porcentaje de $\mathrm{SnO}_{2}$ es muy variable en las muestras analizadas (desde $0,64 \%$ a $15,62 \%$ ), tomando como media una baja opacificación, menor en la producción de Manises, en la primera etapa, que en la de Paterna.

En el transcurso de siglos de evolución, y a partir especialmente del siglo XVIII, se alcanza el grado de blancura y opacidad equiparable en calidad a las producciones industriales del siglo XX.

En la producción valenciana, la paleta de color quedará reducida al azul, obtenido a partir del óxido de cobalto, con diferentes intensidades en función de su composición y densidad; los verdes del óxido de cobre, el cual se obtendrá calcinando el cobre metálico; los perfilados y rellenos de marrón negruzco a partir del $\mathrm{MnO}_{2}$, directamente triturando el mine- protection boxes and clay colomins to separate pieces from others). In many $15^{\text {th }}$ century samples the three marks left by the contact of the tripod on the glaze can no longer be seen.

Special attention should be given to the preparation of white tin glazing. The earliest Hispano-Moresque glazed ceramic work resorted to lead frit as the basic frit for all its glazes, obtained from galena (lead sulphide) and siliceous sand. These glazes were coloured all together to obtain the basic palette used in tile-making: for white, by adding a low percentage of opacifier $\left(\mathrm{SnO}_{2}\right)$; blue, with or without opacifier, from $\mathrm{CoO}$ (açafre); turquoise from $\mathrm{CuO}$ on a composition of alkaline frit with little or no lead content; the honey colour was obtained with iron oxide diluted in lead silicate; green from $\mathrm{CuO}$ on lead base; brown/violet from $\mathrm{MnO}_{2}$ and black glazes with a high percentage of manganese, iron and cobalt on a base frit.

Yellow glazes and colours are not found until the $16^{\text {th }}$ century, when these were brought in from Italy, based on a composition of antimonious lead.

This scanty but sufficient palette of glazes and colours used in Hispano-Moresque ceramics was reduced, in the case of medieval Valencian ceramic tiles, to the use of a single base glaze (lead frit made opaque with tin) and exceptionally, the same non-opacified glaze as a cover layer.

From the early direct use of galena potters went on to work directly with metal lead which was subjected to an oxidation process in a reverbatory furnace, stirring the lead with a paddle (dragó) until full oxidation was obtained ( $\mathrm{PbO}$ or $\mathrm{Pb}_{3} \mathrm{O}_{4}$ ). Lead ochre or minium, known as acercó, was carefully mixed with siliceous sand and sea salt, and fritted along with the tin or separately from this, in recipients placed in the sachén of the kiln, with a possibility of either preparing the base frit and mixing this afterwards with the calcina obtained from the lead and tin fritting process, or incorporating the tin directly in the base frit. Unlike later Italian maiolica, no phosphorous was added to the composition through organic material (as was the case of the wine sediment incorporated in marzacotto).

After the fritting operation there was a crushing and grinding process, sometimes by means of trunco-conical grindstones driven by animal power, until getting the water dispersion of the enamel at the right granulometry to be properly applied over the biscuit.

The lead was imported from Venice, normally of German origin, whilst the tin came from the Netherlands and England. Throughout history, both products were a problem for Valencian ceramic production, and in particular tin, obtained from grain tin, due to its high price and through the duties and difficulties that its importing involved.

According to archeometric studies the percentage of $\mathrm{SnO}_{2}$ is highly variable in the samples analysed (from $0.64 \%$ to $15.62 \%$ ) taking on average a low opacification, less in Manises production in the early stages than in that of Paterna.

In the course of centuries of evolution, and particularly from the $18^{\text {th }}$ century, a degree of whiteness and opaqueness comparable in quality to the $20^{\text {th }}$ centuries industrial productions was attained.

In Valencian production, the colour palette came down to blue, obtained from cobalt oxide, with different intensities depending on its composition and density; greens of copper oxide, which were obtained by roasting the metallic copper; blackish brown outlines and fillings by using $\mathrm{MnO}_{2}$, directly crushing the mineral and either using this alone or in combinations with iron oxide. 
ral, utilizado solo o en composiciones con óxido de hierro.

No están presentes los melados de hierro ni los turquesas de cobre sobre base alcalina.

Exceptuando la oxidación del cobre, se desconoce cualquier tratamiento térmico en la paleta de color. Sí se constatan los trabajos de reducción de tamaño y preparación de las cuidadas dispersiones para la aplicación de los colores, tanto en relleno como en perfilados.

También en base a los estudios arqueométricos, se documenta que la decoración mayoritaria se efectúa directamente sobre el bizcocho y excepcionalmente sobre engobe, aplicando el vidriado estannífero encima, con lo que debemos hablar de una decoración bajo esmalte, con personalidad propia y diferenciadora respecto a la producción italiana de mayólica, que decorará directamente sobre el vidriado estannífero. En la medida que aumenta la opacidad y marca del vidriado, se invertirá la técnica decorativa.

En todos los casos se habla de decoración manual, de delineación directa o a partir de estarcido. Excepcionalmente se utilizarán plantillas, como un antecedente de la decoración a trepa (escudos nobiliarios, la rotulación gótica y algunos motivos florales o geométricos).

\section{V.2 Los lustres de pigmentos reducidos}

Esta técnica que hoy se denominaría de tercer fuego, constituye la máxima expresión de la tecnología cerámica hispanomusulmana y la principal baza del éxito comercial de la producción valenciana medieval.

Es importada a la Península por los ceramistas emigrados desde Persia ya en la época califal, a su vez procedente de la tecnología de decoración del vidrio, desarrollada en Egipto por el Arte Copto y reconducida por la Dinastía Fatimí. Alcanza su máxima expresión durante el largo reinado Nazarí en los alfares de Málaga y Granada, y es importada a Valencia seguramente por los Boill. La composición de los lustres y la técnica de aplicación fueron un secreto que se transmitía de padres a hijos en el lecho de muerte y que se ejecutaba en un contexto de máxima discreción fuera de la vista de los operarios.

En su composición entran básicamente el cobre y la plata, que primero se calcinan para convertirlos en óxidos, con otros aditivos que favorecen, en las diferentes fases de la cocción, el proceso de oxidación/reducción necesario para conseguir la iridiscencia de la decoración final. En composiciones sofisticadas interviene el óxido férrico (tierra de Almágena o Almagre), el ácido nítrico e incluso cinabrio. La composición diluida en una frita plúmbica debe aplicarse en forma de dispersión con vinagre sobre el vidriado estannífero ya cocido, en una sutil capa que favorecerá la transparencia de la metalización y la reflexión selectiva de la luz (fenómeno de iridiscencia).

Los productos decorados con lustres se cocerán en mufla de pequeñas dimensiones (hasta $1 \mathrm{~m}^{3}$ ) en un proceso a baja temperatura $\left(690-720^{\circ}\right)$ que incluirá tres fases diferenciadas: una etapa inicial oxidante, una etapa fuertemente reductora hasta la temperatura máxima, para terminar con una última etapa oxidante hasta el enfriamiento. En función de la calidad del proceso de cocción, el grosor de la capa aplicada a pincel (dispersión del lustre en vinagre) y también de la composición del lustre, obtendremos desde un amarillo paja (dorado con iridiscencias) hasta un rojizo con reflejo metálico.
No iron honey shades or turquoises of copper on an alkaline base are found.

Except for the oxidation of copper no heat treatment in the colour palette is known of, but there were indeed size reduction processes and others for preparing the painstaking dispersions for application of colours, both in the fillings and outlines.

Archeometric studies have also shown that most of the decoration was done directly on the biscuit and exceptionally on the engobe, applying the tin glaze over this, thus meaning that the proper description of this would be decoration under enamel, with its own personality differentiating this from Italian production of maiolica, which decorated directly over the tin glaze. As the opaqueness and mark of the glazing increased, the decorative technique would be inverted.

In all these cases we are talking of decorating by hand, of direct delineation or by using a stencil. Templates would exceptionally be used, as a precursor of trepa stencil decoration (noble families' coats of arms, Gothic lettering, and certain floral or geometrical motifs).

\section{V.2. Reduced pigment lustres}

This technique, which would today be known as third firing, constitutes the highest point in Hispano-Moresque ceramics technology, and the main reason for the commercial success of medieval Valencian production.

This was brought into the Peninsula by ceramic craftsmen who emigrated from Persia as early as the caliphate age, stemming in turn from the glass decoration technology developed in Egypt by Coptic art and reinterpreted by the Fatimi Dynasty. It reached its greatest expression during the long Nazarí kingdom in the Malaga and Granada potteries, and was imported to Valencia by the Boil family, most probably. The composition of the lustres and the technique for applying these were secrets passed on from father to son on their death beds and executed with the greatest discretion far from the sight of the workers.

In their composition these basically included copper and silver, which were first roasted to convert them into oxides, with other additives which in the different phases of firing fostered the oxidation/ reduction process necessary to get the iridescence of the final decoration. In sophisticated compositions ferric oxide was used (Almágena earth or Almagre), nitric acid or even cinnabar. The composition diluted in a lead frit has to be applied in the form of a dispersion with vinegar on the previously fired tin glaze, in a subtle layer which would favour the transparency of the metalling process and the selective reflection of the light (the iridescence phenomenon).

The products decorated with lustres would be fired in small muffle furnaces (up to $1 \mathrm{~m}^{3}$ ) in a low temperature process $\left(690-720^{\circ} \mathrm{C}\right)$ which would include three different phases: an initial oxidation stage, a highly reductive stage, up to maximum temperature, ending with a last oxidising stage up to cooling. Depending on the quality of the firing process, the thickness of the brush-applied coat (dispersion of the lustre in vinegar) and also on the composition of the lustre, one can obtain from a straw yellow (golden with iridescence) to a red with a metal reflection. 


\section{V.3. La evolución posterior}

Tal como se ha dicho al principio, no se producen cambios sustanciales en el proceso de elaboración de las baldosas cerámicas valencianas hasta la introducción de los primeros elementos mecánicos en la conformación. Sobre todo, desde que se inicia el proceso de industrialización y seriación decorativa mediante trepas, que acontece a partir de mediados del siglo XIX.

Las innovaciones atañen más a aspectos formales y calidad de los vidriados. En el primer caso, anotamos la introducción del antimonio como colorante amarillo, que acompaña a la cerámica renacentista y que llega a la península ibérica a través de ceramistas de aquel país. Con el antimoniato de plomo tendremos el amarillo limón (amarillo de Nápoles) que intervendrá en toda la gama de amarillos y naranjas (también en composiciones de verde) de la paleta de color que se desarrolla en la producción valenciana a partir del siglo XVI.

El sistema Sb-Fe-Mn limitará toda la gama de colores entre el amarillo y el marrón oscuro, descartando el rojo, que estará ausente de la decoración hasta el siglo XIX.

En general y a partir de la policromía introducida en la manufactura de Alcora (1.727), la paleta de color quedará sustancialmente ampliada en las producciones del siglo XVIII, marcando como frontera no sólo el inicio de la actividad en la manufactura alcoreña sino el cambio de formato que se produce a partir de la segunda década de ese siglo.

El cromo está ausente de la paleta de color, al menos hasta el siglo XIX, donde ya se constatan los verdes de cromo.

\section{V.4. Los formatos}

El rico repertorio de formatos más o menos complejos de la etapa medieval se va reduciendo en el tiempo, según un criterio de extrema simplificación de los solados y alicatados. Durante una dilatada etapa predomina el formato cuadrado (entre el 11x11 y 14x14 cm), apenas complementado por la pieza rectangular con función de cenefa y cantoneras para zócalos.

A partir de 1.720 se pasará al formato cuadrado de palmo valenciano $(22 \times 22 \mathrm{~cm})$, reconduciendo todo el repertorio decorativo, primero hacia la reconversión de los diseños de a cuatro a pieza única y, después, a un despliegue a mayor escala de los nuevos repertorios con diseño de cuarto.

También aquí se tendrá que esperar a la etapa protoindustrial e industrial para recuperar piezas especiales de entrega y formatos más complejos que configurarán el riquísimo repertorio de cerámica arquitectónica, desde finales del siglo XIX. Ya a finales del XVIII se da una nueva reconversión de formato cuadrado: del palmo valenciano al palmo castellano, apareciendo ese formato universal que es el $20 \times 20 \mathrm{~cm}$.

\section{BIBLIOGRAFÍA / REFERENCES}

Gonzalez Martí, M . Cerámica del Levante Español, Siglos Medievales . Tomo II : Alicatados y Azulejos . Ed. Labor, S.A. Barcelona 1952

Gonzalez Martí, M. Cerámica del Levante Español, Siglos Medievales . Tomo III : Socarrats y Retablos . Ed Labor, S.A. Barcelona 1952

Pérez Guillén, I. V. Cerámica Arquitectónica Valenciana . Los Azulejos de Serie ( S.s. XVIXVIII ) Tomos I y II . Consell Valencià de Cultura , Institut de Promoció Cerámica ISBN 84-482-1357-2 . Valencia 1996

Pérez Guillén , I. V. Cerámica Arquitectónica Valenciana . Los Azulejos de Serie ( S.XIX) Tomos I y II Institut de Promoció Cerámica . En preparación

Cirici, A. ; Manent,R. Cerámica Catalana . Ed. Destino , Barcelona . ISBN 84-233-070691977

\section{V.3. Later evolution}

As was stated at the beginning, there were no substantial changes in the process of preparing Valencian ceramic tiles until the introduction of the first mechanical elements in the forming process, and above all, from the time of industrialisation and decorative serialisation process by means of trepa stencils which started from half way through the $19^{\text {th }}$ century.

The innovations have more to do with formal aspects and the quality of the glazes. In the first case, one must note the introduction of antimony as a yellow colouring, which accompanied renaissance ceramics and which reached the Iberian peninsula through the ceramic craftsmen from that country. Antimonious lead obtained lemon yellow (Naples yellow) which was used in in the whole range of yellows and oranges (also in green compositions) of the colour palette which would be developed in Valencian production from the $16^{\text {th }}$ century.

The $\mathrm{Sb}-\mathrm{Fe}-\mathrm{Mn}$ system would limit the whole range of colours from yellow to dark brown, leaving out red, which would not be found in decoration until the $19^{\text {th }}$ century.

In general, starting from the polychrome range introduced in Alcora manufacturing (1.727), the colour palette would be substantially extended in $18^{\text {th }}$ century production, with the frontier being marked not only by the start of the activity in the Alcora factories but also by the change in size format which started from the second decade of that century.

Chromium would be absent from the colour range at least until the $19^{\text {th }}$ century, when chrome greens would finally be seen.

\section{V.4 Size formats}

The extensive range of more or less complex size formats found in the medieval age gradually diminished in time, through a criterion of extreme simplification of wall and floor tiling techniques. For a long time, the square format (between 11 x 11 and $14 \times 14 \mathrm{~cm}$.) prevailed, barely complemented by the rectangular piece with a frieze function and edge pieces for plinths.

From 1.720 the square Valencian span format $(22 \times 22 \mathrm{~cm}$.) began to come in, changing the whole decorative repertoire, firstly towards changing the a cuatro four-piece designs to a single item, and later to a large scale development of the new repertoires with cuarto design.

Here too we will have to wait for the proto-industrial and industrial stage to recover special custom-made items and more complex formats which would make up the extremely rich range of architectural ceramics, from the end of the $19^{\text {th }}$ century. As early as the end of the $18^{\text {th }}$ century, there was a new reconversion of the square format, going from the Valencian span to the Castilian span, with the universal format of $20 \times 20 \mathrm{~cm}$ now appearing.

Font i Gumà, Joseph. Rajolas valencianas y catalanas. Impresor Oliva, Vilanova i la Geltrú . Edición facsimil. Librería París - Valencia 1905

Soler Ferrer, M M P. . Historia de la Cerámica Valenciana. Tomos II , III y IV . Vicent García Editores S.A. Valencia. ISBN 84-85094-61-1 1986-1989

Gomis Martí, J. M. . Evolució Histórica del Taulellet. Servei de Publicacions de la Diputació de Castelló , ISBN 84-86895-19-7. 1990.

Peréz Guillén I. V. La Pintura Cerámica Valenciana del S XVIII . Edicions Alfons el Magnanim , Institució Valenciana D’Estudis i Investigació. ISBN 84-7822-015-1. 1991 Ceramics and Civilization. Vol. I, Ancient Technology to Modern Science. W. D. Kingery. $13 \mathrm{TH}$ to $18 \mathrm{TH}$ century ceramics from the Paterna-Manises area (Spain). A Jornet, M. J. Blackman, J. S. Olin (235-255) Ed. Amer. Ceram. Soc. 1985 